\title{
The analysis of contextual variables affecting the efficiency of fiscal rules in the EU
}

\author{
Maja Mihelja Žaja ${ }^{1, *}$, Gordana Kordić ${ }^{1}$, Margareta Gardijan Kedžo ${ }^{1}$ \\ ${ }^{1}$ Faculty of Economics and Business, University of Zagreb \\ Trg J. F. Kennedyja 6, 10000 Zagreb, Croatia \\ E-mail: 〈\{mmihelja,gkordic, mgardijan\}@efzg.hr〉
}

\begin{abstract}
Fiscal rules are among the cornerstones of macroeconomic policies in the European Union, both on the national and the supranational level. The importance of enacting and conducting the fiscal rules has become apparent after the expansion of public debts and budget deficits in the period of the global financial crisis. Besides the supranational rules, governments impose national fiscal rules in order to fulfill the convergence criteria for public debt and the budget deficit. Still, there is an open question on their influence on other economic parameters. This paper examines contextual variables that influenced the efficiency of implementing fiscal rules in 28 European Union countries. We observe the period of the last financial crisis and its aftermath when most of the countries introduced new or adjusted existing national fiscal rules, using two-stage Data Envelopment Analysis (DEA). The main goal of the paper is to study the impact of contextual variables on fiscal rules' efficiency scores. In the first stage, we specify the DEA model to estimate the relative efficiency for each observed country in each year in the period from 2008 to 2016. After that, in the second stage, the efficiency scores are regressed on several contextual variables to observe the factors that explicate the variation in DEA-efficiency.
\end{abstract}

Keywords: contextual variables, data envelopment analysis, efficiency, EU-28, fiscal rules

Received: October 23, 2018; accepted: April 17, 2019; available online: July 4, 2019

DOI: $10.17535 /$ crorr.2019.0014

\section{Introduction}

The rules of fiscal policy represent constraints on fiscal outcomes such as the budget deficit, public debt, income or expenditure. They can be expressed in absolute terms or relative to a certain economic variable. Special attention has been devoted to fiscal rules after the economic crisis in 2008. Although the global financial crisis emerged from the banking sector, in order to support banks governments implemented measures that led to the increase of deficits and debts. This escalation was interpreted as a lack of fiscal discipline and national governments were urged to implement new or strengthen existing supranational and/or national fiscal rules. The main intention was to assure better fiscal responsibility, reliability, and the sustainability of public debt. Ultimately, managing public finances should have become more efficient, and without unnecessary public spending, in good and successful periods. However, not all researchers agree that the presence of rules is a warranty for fiscal precaution. On the contrary, opponents proclaim that the enhancement of fiscal discipline occurs at the expense of macroeconomic indicators and the actual impact of these rules on fiscal discipline is ambiguous. Fiscal rules cannot act on their own and must be supported by changes in both the economical and the political aspects where an appropriate institution enforces them with supervisory mechanisms.

${ }^{*}$ Corresponding author. 
In 1990, only five countries (Germany, Indonesia, Japan, Luxembourg and the USA) applied fiscal rules and until 2015 fiscal rules were in force in 96 countries [25]. Furthermore, national and supranational fiscal rules can be classified in four categories: balanced budget rule (BBR), debt rule (DR), expenditure rule (ER) and revenue rule (RR), which can be applied to the central or general government or the public sector [25].

In this paper, we explore external factors which could improve or deteriorate countries' efficiency in conducting fiscal rules. In the first stage of our analysis we use Data Envelopment Analysis (DEA) and an output-oriented BCC model (Banker, Charnes and Cooper, [7]) on the 28 European Union countries in the period from 2008 until 2016. We observed this period in order to investigate the impact of changes in fiscal rules on the efficiency of conducting fiscal rules just after the financial crises and after 2012 when 25 member states of the European Union (EU) signed the new agreement on fiscal sustainability "Fiscal Compact" or the Treaty on Stability, Coordination and Governance in the European Monetary Union (EMU). This arrangement introduced certain new features to the fiscal rules at a national level and reinforced the framework for fiscal management implicitly in the Pact for Stability and Growth.

In DEA, the efficiency of units is estimated given the values of their inputs (variables whose values we prefer to be as small as possible) and their outputs (variables whose values we prefer to be as great as possible). As input variables, we use: deviation from the agreed level of debt; deviation from the agreed deficit/surplus level; and, expenditure (all in \% of gross domestic product (GDP). For outputs, we use revenue (in \% of GDP), GDP growth rate and employment rate. In the second stage, obtained efficiency scores are regressed on chosen contextual variables in order to estimate their influence on the efficiency of conducting fiscal rules.

There are numerous papers written on the subject of fiscal rules, and brief review of the relevant literature is given in section 2. Data Envelopment Analysis as a nonparametric mathematical programming approach is used in a variety of fields and problems, including economics and public-sector efficiency evaluation. Nevertheless, and according to our best knowledge, there are no papers using two-stage DEA in evaluating the influence of contextual variables on the efficiency of fiscal rules in the EU countries. Therefore, the main contribution of this paper is in selecting and defining variables which could impact on the efficiency score. As contextual variables, we used indicators for four fiscal rules (BBR, DR, ER, RR) as dummy variables. In addition, we incorporated five macroeconomic variables which we presume to have a significant impact on the efficiency of conducting fiscal rules: inflation rate, credit rating, unemployment rate, employers' social contributions and social protection benefits.

The paper is organized in five sections. After the introduction, in Section 2, we discuss prior research on fiscal rules and propose our research hypotheses. In Section 3, methodology and data are described, and the results are given in Section 4. Section 5 concludes.

\section{Background}

Numerical targets for different fiscal variables, termed as fiscal rules, are oriented towards enhancing macroeconomic discipline and contributing to fiscal discipline in the long run. As the number of EU countries that implement fiscal rules had increased in past decades, there has been a growing interest in the efficiency of conducting fiscal rules and their impact on other economic variables.

\subsection{Literature review}

Fiscal rules for the European Union countries are an important part of the integration process and a precondition for stable functioning of the monetary union. The potential Eurozone member countries are oriented to fulfilling the supranational Maastricht criteria that also include implementation of national rules. The open question is whether countries, in order to solve a 
crisis, should rely on stronger government spending or use austerity measures. As described in the literature $([19,25])$ one of the main goals of fiscal rules is to strengthen fiscal discipline and to contribute to fulfilling of fiscal policy and macroeconomic goals, both in national and supranational terms. They indirectly contribute to the fulfilling of Maastricht criterions as supra-national rules in the European Union countries (although even more important to countries outside the Eurozone). The deterioration of the fiscal discipline during the Great Recession threatened the stability of the European monetary union which raised doubts about its future and monetary integration process in general, including reforms in the fiscal framework.

Description of the characteristics, including pro and contra, of different fiscal rules, is given in Eyraud et al. [16] with a focus on the choice of a particular rule. Still, there are numerous analyses of the effectiveness of a certain rule and the optimality of its selection from different aspects. Auerbach [4] summarises the knowledge of fiscal rules from theory and evidence in ten lessons. Doray-Demers and Foucault [10] analysed different theories regarding national fiscal rules stringency for a panel of 28 European countries in the period of 1990-2013, concluding that the fiscal stress in the short term prevents fiscal reform, but in the long term it results in stronger fiscal rules. National fiscal rules, introduced on a path to the European Union membership, were a part of a commitment to Maastricht criterion fulfillment. However, national fiscal rules were more stringent after the 2009 sovereign debt crisis in order to obtain fiscal support from the EU. In their study, Landon and Smith [21] investigated the benefits of different fiscal rules, comparing them and searching for benefits of a particular rule, using data for European Union countries and the Monte Carlo method. Still, there is an open question of whether introducing a fiscal rule contributes to the decreasing (and/or controlling) of the public sector debt. Research on macroeconomic effects of fiscal rules provided in Altunbaş and Thornton [1] on a sample of 110 countries (58 with fiscal rule), during 1970-2012 resulted in a list of factors that should be considered. They found that a probability that a country will adopt a debt rule is greater in countries with high public debt, relatively inflexible exchange rate and with deep credit market that are already using an inflation targeting regime. Furthermore, countries are prone to introduce the rule following positive experiences of other countries. Finally, Altunbas and Thornton [1] find that countries that are preparing for the introduction of fiscal rules need to improve their macroeconomic performance and institutional framework, with the support from monetary and other policies. Badinger and Reuter [5] used a two-stage least squares estimates on a sample of 79 countries during 1985-2012 in order to investigate the relevant determinants of fiscal rules. The analysis concluded that countries with more stringent fiscal rules have higher fiscal balances, lower interest rate spreads on government bonds and lower output volatility. The impact of fiscal rules on sustainable development has been researched on a sample of the Visegrad Group Countries by Hölscher et al. [17] and resulted in several conclusions. The authors have proven a significant effect of fiscal rules on financial markets' perception of fiscal measures (that is further spilled over to the public sector cost of capital). Implementation of fiscal rules has a positive impact on real economic growth, but rules are not resistant to economic shocks and do not protect public sector stability in times of crisis. Finally, a stronger impact of fiscal rules on economic policy leads to a negative impact on social indicators, including stronger social exclusion and income stratification. Aristovnik and [2] focused on the fiscal behavior of EMU member states in terms of supranational rules (Maastricht criterion and Stability and Growth Pact), observing changes in the incentives before and after entering the EMU. They concluded that there has been a difference in fiscal behaviour - countries had stronger motivation to comply with fiscal rules in the Maastricht period, but the motivation later decreased.

\subsection{Research hypothesis}

Decentralized national fiscal policies in terms of monetary union need harmonization in order to provide full support for macroeconomic stability. Supranational fiscal rules were first defined 
in the Maastricht criteria, followed by the Stability and Growth Pact, and they refer to general government debt and fiscal deficit (as a \% of GDP). Although the main rules remained the same, during the previous economic crisis they were adjusted with additional requirements that have been elaborated in detail in International Monetary Fund (IMF) papers [11] [12]. Besides the supranational rules, and in order to fulfill the predefined criteria, member countries also introduce national numerical fiscal rules [13].

Still, the questions of the actual efficiency of the fiscal rules, the optimality of their definition and the criteria used remain open, both in theory and practice. The efficiency of fiscal rules was analysed using Data Envelopment Analysis in [20] using data from [22] and [25]. The analysis provided in this paper follows that research, aiming to define the contextual variables that influence and describe the efficiency of conducting fiscal rules in terms of fulfilling the Maastricht criteria. For that purpose, nine contextual variables were introduced and tested: $\mathrm{BBR}, \mathrm{DR}, \mathrm{ER}$ and RR (as dummy variables), inflation rate, credit rating, unemployment rate, employers' social contributions, and social protection benefits. The choice of using national rules as indicator variables is quite straightforward. We assume that the application of national rules should be an important factor for fiscal efficiency. Inflation rate, as a contextual variable, was introduced as an indicator of the influence of the monetary variables on the fiscal policy. It also reflects the stability of prices, which is the final goal of monetary policy in the majority of countries observed, and, as a part of the Maastricht criteria. Furthermore, changes in fiscal policy (especially in terms of fiscal expansion) might cause an increase in inflation rate. An increase of inflation rate might endanger fiscal rules efficiency. Credit rating is a sign of the general stability of a country in terms of international capital markets. Better efficiency in the definition and implementation of fiscal rules should positively contribute to this indicator and vice versa. Unemployment rate as a macroeconomic variable was chosen as an indicator of poor economic conditions and an increased instability in a country. A high unemployment rate leads to fewer revenues from taxes, both personal income tax and consumption taxes, which finally leads to the increase in public debt and the inability of a country to fulfill its fiscal rules. Employers' social contributions and social protection benefits are related to unemployment since, with fewer employees, social contributions decline and governments have to find another way to finance social benefits for their population. Social contributions included in this research are employers' actual social contributions which contain payments made by employers for the benefit of their employees to insurers (social security funds, general government and private funded schemes) [14]. Social protection benefits are transfers to households with the intention of taking over the financial burden of risks of disability, sickness/healthcare, old age, survivors, family/children, unemployment, housing and social exclusion not covered elsewhere. During the last financial crisis, these expenditures increased by $2.8 \%$ on the EU level, and they made up $96.3 \%$ of the EU-28's social protection expenditure [14]. This places an additional burden on the governments' budget and consequently their ability to fulfill fiscal rules.

Since the economic crisis was a trigger to introduce stringent fiscal rules and correct excessive consumption in order to assure fiscal responsibility, credibility, and sustainability of public debt through fiscal discipline, we focus our research on the period from 2008 to 2016. This period is known as the period of a new generation of fiscal rules [21, 25]. Not only did countries introduce and modify fiscal rules on a national level, but in 2012 rules on a supranational level were revised and complemented.

This leads to the following research hypothesis: the introduction and enhancement of fiscal rules on a national level, after the crisis, leads to an increase of efficiency in conducting and fulfilling Maastricht criteria. In other words, in order to fulfill the Maastricht criteria, countries implemented fiscal rules on a national level.

We must keep in mind that the crisis was not caused by high public debts, but vice versa, and that the existence of a rule is not a guarantee of fiscal prudence and the efficiency of conducting fiscal rules. IMF identified four types of fiscal rules, but each country was able to 
select and adjust a certain rule to the macroeconomic condition in the country. When analysing imposed rules we can see that countries mostly used a balanced budget rule and an expenditure rule [20], so these two rules are of special interest for our analysis.

\section{Methodology and data}

In the first stage of our analysis we use DEA, namely, the output-oriented BCC model [7] to obtain countries' efficiency scores. This model was selected because it assumes variable returns to scale which is in accordance with the nature of this research and it can handle negative and missing data which allows keeping all units in the dataset [24]. The formulation of the BCC model is as follows.

Let there be $N$ decision-making units (DMUs): $D M U_{1}, D M U_{2}, \ldots, D M U_{N}$ which are homogenous and comparative. We assume that their efficiency is defined by a certain number of input variables whose values we want to be as small as possible and a certain number of output variables whose values we like to be as big as possible. Let $x_{i j}>0$ be an $i$-th input for some $D M U_{j}, i \in\{1,2, \ldots, n\}$ and $y_{r j}>0$ its $r$-th output, $r \in\{1,2, \ldots, m\}, j \in\{1,2, \ldots, N\}$. Each $D M U_{j}$ is represented by a vector of inputs $\mathbf{X}_{j}=\left(x_{1 j}, x_{2 j}, \ldots, x_{n j}\right)$ and vector of outputs $\mathbf{Y}_{j}=\left(y_{1 j}, y_{2 j}, \ldots, y_{m j}\right)$. According to [9] the measure of efficiency $\phi$ in the output-oriented model, is obtained by solving the following linear program for each $D M U_{0}=D M U_{j}$ :

$$
\begin{aligned}
& \max _{\lambda, \phi} \phi+e\left(s^{+}+s^{-}\right) \\
& \sum_{j=1}^{N} \mathbf{X}_{j} \lambda_{j}+s^{-}=\mathbf{X}_{0} \\
& \sum_{j=1}^{n} \mathbf{Y}_{j} \lambda_{j}-s^{+}=\phi \mathbf{Y}_{0} \\
& \sum_{j=1}^{N} \lambda_{j}=1 \\
& \lambda_{j} \geq 0, \quad j \in\{1,2, \ldots, N\}
\end{aligned}
$$

where $s^{-}$and $s^{+}$are vectors of slack variables. If we denote the optimal solution as $\left(\phi^{*}, \lambda^{*}, s^{-*}\right.$, $\left.s^{+*}\right)$ then $D M U_{0}$ is efficient if and only if $\phi^{*}=1$ and $s^{-*}=s^{+*}=0$. The parameters $\lambda_{j}$ in the solution of the model are used to identify the peer group of an inefficient DMU.

The aim of the second stage of the analysis is to find the factors that have the statistically significant impact on the DEA fiscal efficiency score of a certain country. Therefore, in the second stage, we perform the Ordinary Least Square (OLS) panel analysis with two-way fixed effects and regress obtained log efficiency scores on a chosen number of contextual variables.

The sample contains data on $28 \mathrm{EU}$ countries in the period of 2008-2016. In the first stage, we treat $28 \mathrm{EU}$ countries as DMUs and determine their relative efficiency using the BCC model on a pooled sample, so each country in each year is treated as an individual DMU. Thus, our relative efficiency evaluation has 252 DMUs and allows comparability of results between years, assuming no relevant technology change [8]. We assume the fiscal efficiency is defined by 3 input-variables and 3 output-variables. Following the supranational fiscal rules [25] for inputs we choose $\mathbf{I}_{1}$ the deviation from the recommended level of debt ( $60 \%$ of the GDP), $\mathbf{I}_{2}$ deviation from the deficit/surplus level ( $3 \%$ of GDP) and $\mathbf{I}_{3}$ the expenditures in $\%$ of GDP. For outputs, we use $\mathbf{O}_{1}$ total revenue (in $\%$ of GDP), $\mathbf{O}_{2}$ GDP growth rate and $\mathbf{O}_{3}$ employment rate. The values of variables with negative observations were shifted to all positive. Data were collected from Eurostat. The descriptive statistics for the input and output variables is given in Table 1. 


\begin{tabular}{|l|rrrrrr|}
\hline inputs/outputs & \multicolumn{1}{|c}{$\mathbf{I}_{1}$} & \multicolumn{1}{c}{$\mathbf{I}_{2}$} & $\mathbf{I}_{3}$ & $\mathbf{O}_{1}$ & \multicolumn{1}{c|}{$\mathbf{O}_{2}$} & $\mathbf{O}_{3}$ \\
\hline mean & 60.2901 & 7.8393 & 46.0444 & 42.4056 & 15.2552 & 64.5167 \\
median & 55.7500 & 7.2000 & 45.5500 & 42.2500 & 15.7000 & 64.0000 \\
max & 176.3000 & 36.3000 & 65.1000 & 56.4000 & 39.4000 & 77.9000 \\
min & 0.0000 & 0.0000 & 27.1000 & 26.4000 & 0.0000 & 48.8000 \\
\hline
\end{tabular}

Table 1: Descriptive statistics of the DEA inputs and outputs

The contextual variables used in the second stage of the analysis are described in Table 2. National rules are observed as dummy variables with the value 1 if a country applies the rule in a certain year and 0 otherwise.

\begin{tabular}{|c|c|c|}
\hline variable & abbrev. & description \\
\hline Inflation rate & $\overline{\mathrm{INF}}$ & harmonized index of consumer prices $(2015=100)$ \\
\hline Credit rating & $\mathrm{CR}$ & $\begin{array}{l}\text { varying from } \mathrm{D} \text { to } \mathrm{AAA}(0=\text { no change, }+1=\text { improvement } \\
\text { or }-1=\text { deterioration observed in successive years })\end{array}$ \\
\hline Unemployment rate & UNEMP & percentage of active population \\
\hline Social contributions & SOCE & employers' social contributions ( $\%$ of GDP) \\
\hline $\begin{array}{l}\text { Social protection } \\
\text { benefits }\end{array}$ & $\mathrm{SOCB}$ & $\begin{array}{l}\text { payable social benefits other than social transfers } \\
\text { in kind ( } \% \text { of GDP) }\end{array}$ \\
\hline Budget balance rule & BBR & dummy variable 0 or 1 \\
\hline Debt rule & DR & dummy variable 0 or 1 \\
\hline Expenditure rule & ER & dummy variable 0 or 1 \\
\hline Revenue rule & $\mathrm{RR}$ & dummy variable 0 or 1 \\
\hline
\end{tabular}

Table 2: Contextual variables (credit rating obtained from the Standard\&Poor's data)

The descriptive statistics of the numerical contextual variables is given in Table 3.

\begin{tabular}{|l|rrrr|}
\hline & \multicolumn{1}{|c}{ INF } & UNEMP & SOCE & SOCB \\
\hline mean & 1.6663 & 4.4905 & 6.1460 & 14.6456 \\
median & 1.4000 & 4.1000 & 5.8000 & 14.3000 \\
max & 7.9000 & 10.1000 & 12.2000 & 20.3000 \\
min & -1.7000 & 0.1000 & 0.0000 & 8.1000 \\
std. dev. & 1.7530 & 2.4239 & 2.5283 & 2.8495 \\
\hline
\end{tabular}

Table 3: Descriptive statistics of the numerical contextual variables

\section{Results and discussion}

We performed a two-stage procedure in analysing the fiscal efficiency of $28 \mathrm{EU}$ countries in the period of 2008-2016. After calculating efficiency score using DEA, in the second stage we regress the efficiency scores on chosen contextual variables that could affect effectiveness in the context of fulfilling Maastricht criteria in the analysed period.

\subsection{The DEA model and efficiency scores}

Using the BCC model we obtained efficiency scores presented in Table 4. We will refer to these results as fiscal efficiency (scores). The average efficiency of $28 \mathrm{EU}$ countries over the nine sample years is 0.912 and, on average, 13 countries were above that score. We can observe 
that countries' average fiscal efficiency improved after 2009. As expected, there was a general decrease in efficiency in 2009, but since then it started to recuperate for most of the countries. 2008 was the year when seven countries reached score 1 meaning that they were extremely successful in conducting fiscal rules. When looking at the average efficiency by country, we see that Estonia is the country with the highest average efficiency due to the fact that it reached score 1 in all years except 2012 and 2013. Although efficiency rises after 2009, the significant increase occurs after 2012 when "Fiscal Compact" was signed.

\begin{tabular}{|c|c|c|c|c|c|c|c|c|c|c|}
\hline & 2008 & 2009 & 2010 & 2011 & 2012 & 2013 & 2014 & 2015 & 2016 & Avg. \\
\hline $\mathrm{BE}$ & 0.925 & 0.874 & 0.918 & 0.916 & 0.915 & 0.934 & 0.940 & 0.933 & 0.930 & 0.921 \\
\hline BG & 1.000 & 0.883 & 0.906 & 1.000 & 1.000 & 0.936 & 0.846 & 0.919 & 0.969 & 0.940 \\
\hline $\mathrm{CZ}$ & 0.925 & 0.865 & 0.878 & 0.899 & 0.878 & 0.926 & 0.933 & 0.962 & 0.996 & 0.918 \\
\hline DK & 1.000 & 0.986 & 0.992 & 0.988 & 0.979 & 0.982 & 1.000 & 0.985 & 0.997 & 0.990 \\
\hline $\mathrm{DE}$ & 0.950 & 0.906 & 0.953 & 0.965 & 0.965 & 0.965 & 0.975 & 0.981 & 0.986 & 0.961 \\
\hline $\mathrm{EE}$ & 1.000 & 1.000 & 1.000 & 1.000 & 0.976 & 0.984 & 1.000 & 1.000 & 1.000 & 0.996 \\
\hline IE & 0.928 & 0.820 & 0.811 & 0.808 & 0.799 & 0.838 & 0.895 & 1.000 & 1.000 & 0.878 \\
\hline EL & 0.809 & 0.781 & 0.765 & 0.786 & 0.825 & 0.869 & 0.895 & 0.879 & 0.948 & 0.840 \\
\hline ES & 0.873 & 0.775 & 0.778 & 0.762 & 0.737 & 0.787 & 0.819 & 0.838 & 0.850 & 0.802 \\
\hline $\mathrm{FR}$ & 0.906 & 0.880 & 0.917 & 0.934 & 0.922 & 0.938 & 0.945 & 0.948 & 0.950 & 0.927 \\
\hline HR & 0.880 & 0.814 & 0.805 & 0.798 & 0.823 & 0.833 & 0.845 & 0.899 & 0.942 & 0.849 \\
\hline IT & 0.870 & 0.849 & 0.881 & 0.878 & 0.888 & 0.890 & 0.897 & 0.911 & 0.905 & 0.885 \\
\hline $\mathrm{CY}$ & 0.992 & 0.910 & 0.907 & 0.887 & 0.858 & 0.840 & 0.818 & 0.920 & 0.961 & 0.899 \\
\hline LV & 0.974 & 0.796 & 0.774 & 0.889 & 0.933 & 0.944 & 0.940 & 0.954 & 0.975 & 0.909 \\
\hline LT & 0.929 & 0.795 & 0.817 & 0.883 & 0.901 & 0.919 & 0.967 & 0.974 & 1.000 & 0.909 \\
\hline LU & 1.000 & 0.970 & 0.948 & 0.950 & 0.942 & 0.958 & 0.975 & 0.972 & 0.974 & 0.965 \\
\hline $\mathrm{HU}$ & 0.879 & 0.854 & 0.871 & 0.866 & 0.881 & 0.913 & 0.932 & 0.941 & 0.914 & 0.895 \\
\hline MT & 0.852 & 0.852 & 0.889 & 0.883 & 0.865 & 0.889 & 0.916 & 0.928 & 0.985 & 0.895 \\
\hline NL & 1.000 & 0.991 & 0.969 & 0.965 & 0.959 & 0.950 & 0.952 & 0.968 & 0.987 & 0.971 \\
\hline $\mathrm{AT}$ & 0.939 & 0.907 & 0.942 & 0.953 & 0.937 & 0.935 & 0.937 & 0.941 & 0.939 & 0.937 \\
\hline PL & 0.878 & 0.813 & 0.816 & 0.861 & 0.858 & 0.855 & 0.872 & 0.893 & 0.902 & 0.861 \\
\hline $\mathrm{PT}$ & 0.890 & 0.849 & 0.869 & 0.830 & 0.826 & 0.857 & 0.860 & 0.879 & 0.903 & 0.862 \\
\hline $\mathrm{RO}$ & 1.000 & 0.800 & 0.825 & 0.840 & 0.875 & 0.912 & 0.930 & 0.942 & 0.909 & 0.893 \\
\hline SI & 0.955 & 0.875 & 0.880 & 0.856 & 0.858 & 0.841 & 0.883 & 0.902 & 0.910 & 0.884 \\
\hline SK & 0.915 & 0.799 & 0.826 & 0.855 & 0.853 & 0.881 & 0.884 & 0.896 & 0.908 & 0.869 \\
\hline FI & 1.000 & 0.936 & 0.966 & 0.976 & 0.957 & 0.973 & 0.973 & 0.961 & 0.978 & 0.969 \\
\hline SE & 0.973 & 0.951 & 1.000 & 0.977 & 0.952 & 0.970 & 0.981 & 1.000 & 0.998 & 0.978 \\
\hline UK & 0.927 & 0.901 & 0.906 & 0.903 & 0.912 & 0.922 & 0.944 & 0.953 & 0.969 & 0.926 \\
\hline Avg. & 0.935 & 0.873 & 0.886 & 0.897 & 0.896 & 0.909 & 0.920 & 0.938 & 0.953 & 0.912 \\
\hline
\end{tabular}

Table 5: DEA efficiency scores per year and per country (the names of the EU member states are abbreviated according to ISO country codes)

There are obviously significant differences in the efficiencies of conducting fiscal rules between the countries in our sample. This is not surprising given that $28 \mathrm{EU}$ countries have different economic policies, different fiscal rules and, basically, that fiscal policy operates under different conditions. Therefore, we are interested in defining the variables that determine the 'environment' of the fiscal policy. In many DEA papers, the exogenous variables that are used to explain the efficiency scores are called contextual variables and essentially they present the factors that could explain the differences in the efficiency between the DMUs [7]. 

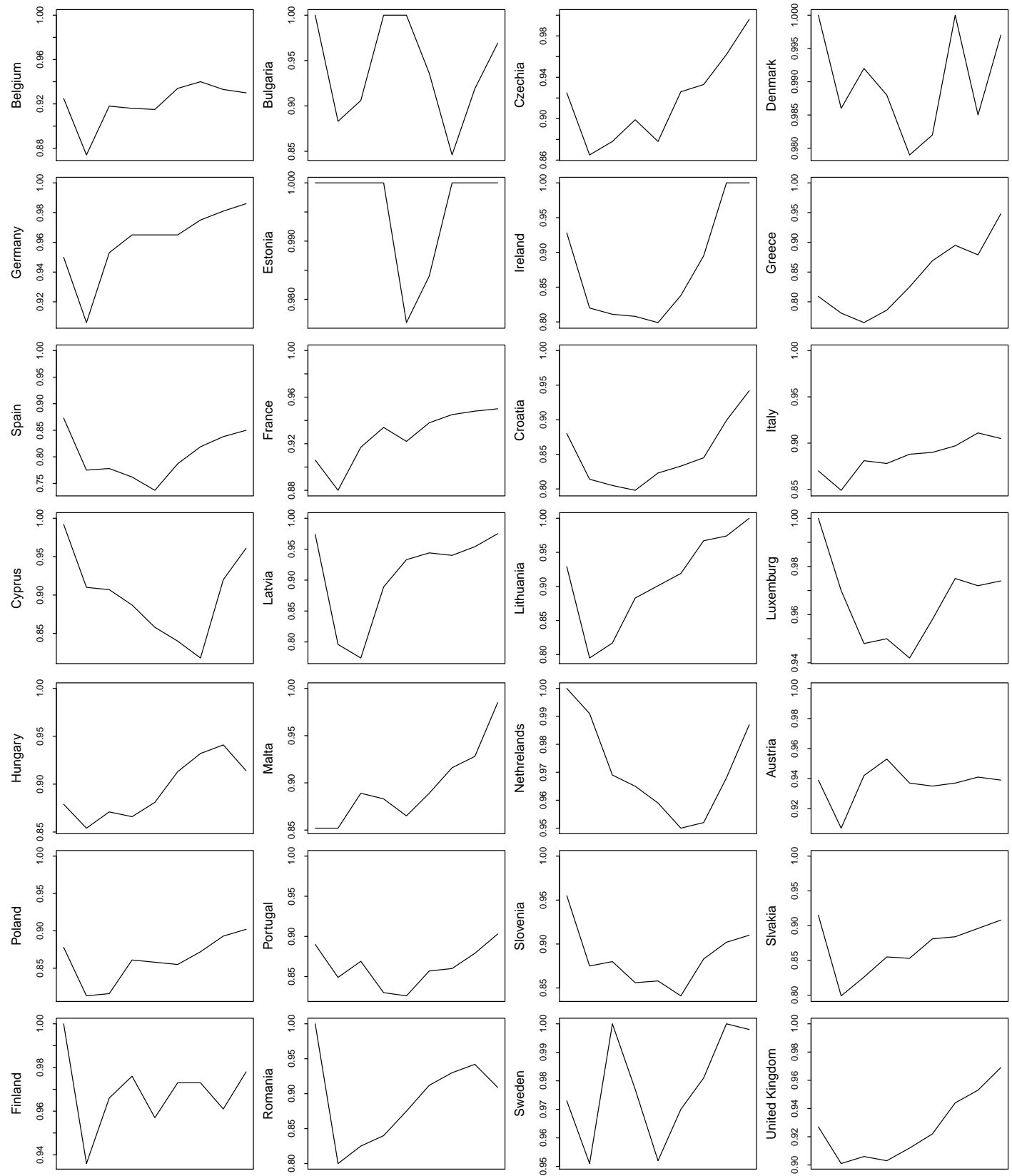

Figure 1: DEA efficiency time-series 
The analysis of contextual variables affecting the efficiency of fiscal rules in the EU

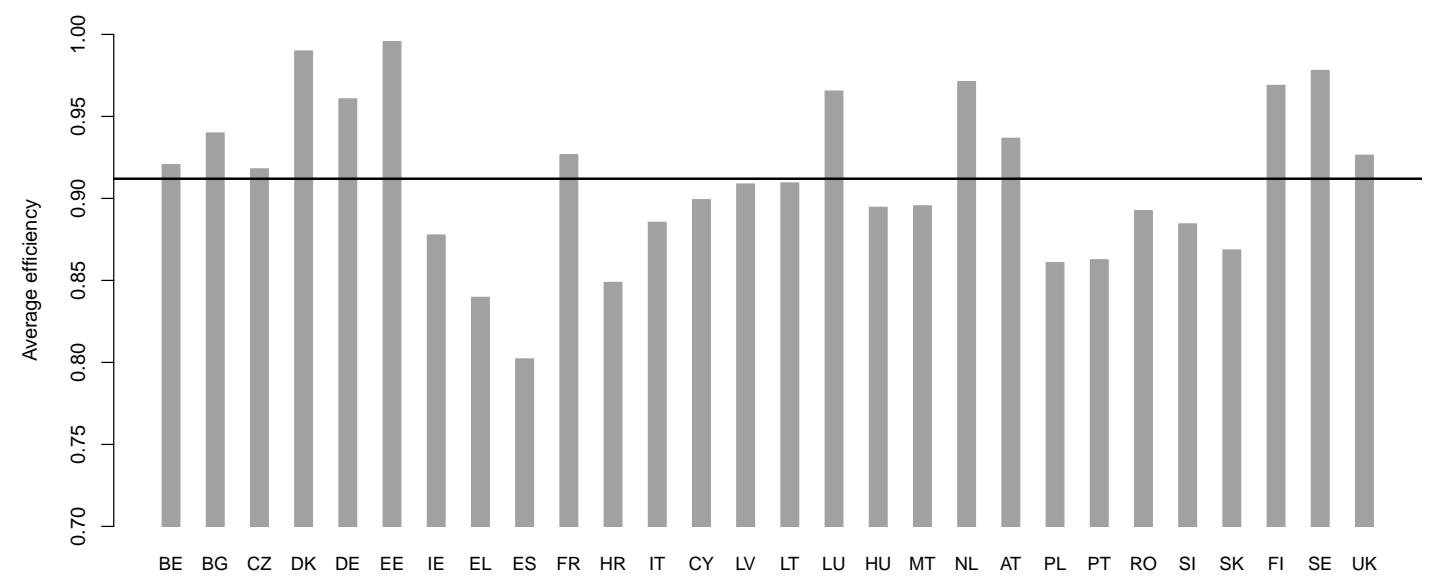

Figure 2: Average DEA scores by country (period 2008-2016)

\subsection{Regression analysis and empirical results}

Following the papers [6] and [23], we estimate the two-way fixed effects model:

$$
\begin{aligned}
\log B C C_{i t}= & \beta_{0}+a_{i}+b_{t}+\beta_{1} E R_{i t}+\beta_{2} D R_{i t}+\beta_{3} R R_{i t}+\beta_{4} B B R_{i t}+\beta_{5} U N E M P_{i t} \\
& +\beta_{6} C R_{i t}+\beta_{7} I N F_{i t}+\beta_{8} S O C E_{i t}+\beta_{9} S O C B_{i t}+\varepsilon_{i t}
\end{aligned}
$$

where $a_{i}$ are cross-section fixed effects and $b_{t}$ are period fixed effects. We were able to reject the null for Hausmann test and tests for redundant fixed effects and therefore validate the two-ways fixed effects approach [3]. The regression results are reported in Table 6. When we include all variables in the equation, we conclude that with $p>0.2 \mathrm{DR}$ and $\mathrm{RR}$ are not significant, as well as the inflation rate and employers' social contributions. As expected, unemployment rate, social protection benefits, and inflation rate have a negative influence on the fiscal efficiency. Others have a positive impact.

\begin{tabular}{|l|ccc|}
\hline dependent: $\log$ BBC & expected sign & $(1)$ & $(2)$ \\
\hline constant & & $0.166831^{* * *}$ & $0.161312^{* * *}$ \\
ER & + & $0.018040^{* *}$ & $0.018840^{* *}$ \\
DR & + & 0.001276 & 0.000811 \\
RR & + & 0.012033 & 0.012561 \\
BBR & + & $0.014316^{*}$ & $0.015154^{*}$ \\
UNEMP & - & -0.000562 & \\
CR & + & $0.007551^{*}$ & $0.007936^{*}$ \\
SOCE & + & 0.005579 & 0.004798 \\
SOCB & - & $-0.021552^{* * *}$ & $-0.020519^{* * *}$ \\
INF & - & -0.001608 & -0.001677 \\
\hline Observations & & 252 & 252 \\
Adj. R-squared & & 0.794544 & 0.795327 \\
\hline
\end{tabular}

Table 6: Regression output (statistical significance at 10\%, 5\% and $1 \%$ are denoted by ${ }^{*},{ }^{* *},{ }^{* * *}$ ) 
Column (2) of Table 6 reports the results when we drop variable UNEMP (unemployment rate), which is highly correlated with input variables, since the performance of the second stage regression is most reliable when contextual variables are not highly correlated with input variables $[7,18]$. The results are robust, and we can conclude that BBR, ER, and country rating have a statistically significant positive impact on fiscal efficiency score at significance level of 0.05. On the other hand, an increase in social protection benefits plays a negative role in the fiscal efficiency score. Other variables are shown to be statistically insignificant.

Overall, our results suggest that countries which implemented a budget balance rule (BBR) and expenditure rule (ER) had, on average, greater efficiency of conducting fiscal rules during our sample period. Also, countries which achieved a positive change of credit rating had, on average, greater fiscal efficiency by $0.7 \%$. Social protection benefits are also significant contextual variable in assessing the efficiency of conducting fiscal rules, since their decrease implies an average increase in efficiency by $2 \%$.

In the end, the analysis of the specific characteristics of the countries, which could be observed in the cross-section fixed effects, is beyond the research of this paper. The period fixed effects estimated by equation (2) are shown on Figure 3. It is obvious that they were negative in the period of 2009-2012 but, from 2013 onwards, their positive and increasing values indicate an annual growth in fiscal efficiency and recovery from the crisis.

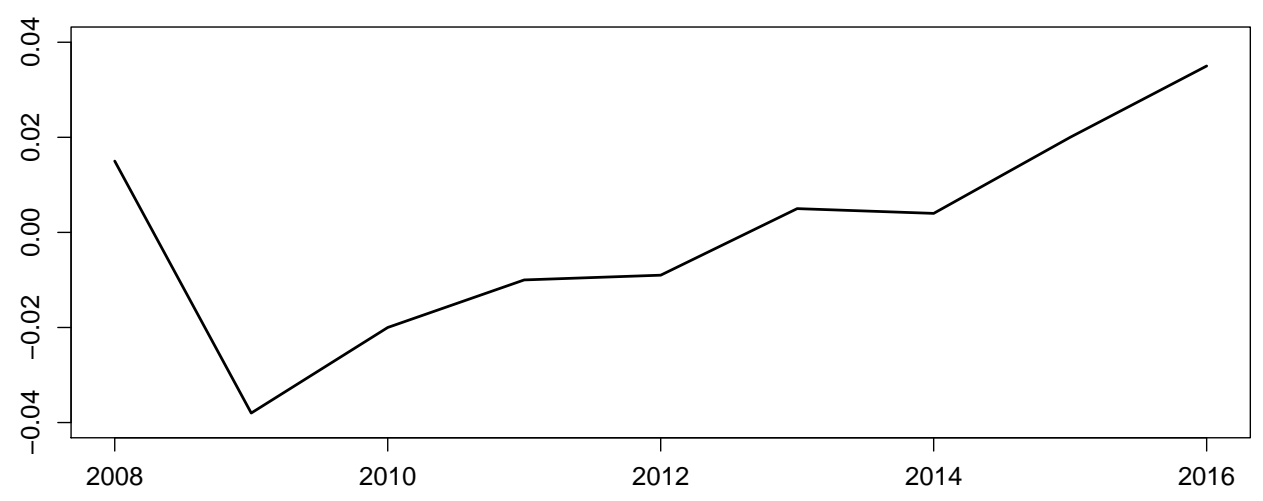

Figure 3: Period fixed effects

\section{Conclusion}

In this research, we have analysed the influence of several contextual variables on the relative efficiency of conducting fiscal rules in $28 \mathrm{EU}$ countries in the period from 2008 until 2016 using the two-stage DEA approach. EU countries were analysed as DMUs whose goal was to fulfill Maastricht treaty rules through national fiscal rules. This case is specific since fiscal policies are defined and implemented on national levels, respecting the supranational EU rules defined by the Maastricht criteria. The period covered in the paper included a past financial crisis that strongly endangered fiscal and general macroeconomic stability at national levels.

At the same time, fiscal rules limited their manoeuvre space for crisis strategies. In the first stage of the analysis, an output-oriented BCC model of DEA was used on panel data and we obtained that the average efficiency for all countries through nine observed years is 0.912 . In the second stage, we used panel analysis to estimate the impact of nine selected contextual variables on efficiency scores. Four of the chosen variables turned out to be insignificant (DR, $\mathrm{RR}$, inflation rate and employers social contributions), and one (unemployment rate) was highly correlated with input variables. 
Statistically significant variables BBR, ER, country rating and social protection benefits contribute to an increase in the fiscal efficiency score. This confirms the main hypothesis of the paper, which stated that the introduction and enhancement of fiscal rules on a national level, after the crisis, leads to an increase of efficiency in conducting and fulfilling Maastricht criteria. The fact that two out of four rules (namely, BBR and ER) positively contribute to the efficiency of conducting fiscal rules indicates that countries should be cautious about the type of fiscal rule they implement. The analysis confirmed that national fiscal rules were well designed in order to improve fiscal discipline and budget stability. The conclusions are made on a general level since the heterogeneity of a group makes it is hard to identify country-specific conclusions. Future research could be carried out for one country or a smaller group of countries with similar features to establish some more specific findings.

\section{Acknowledgements}

We thank Paul Randall of the obex project for language editing support.

\section{References}

[1] Altunbaş, Y. and Thornton, J. (2017). Why do countries adopt fiscal rules? The Manchester School, 85(1), 65-87, doi: 10.1111/manc.12136

[2] Aristovnik, A. and Meze, M. (2017). The impact of supranational fiscal rules on public finance: the case of EMU member states. Global Business and Economic Review, 19(1), 38-53. doi: 10.1504/gber.2017.080781

[3] Asteriou, D. and Hall, G. S. (2011). Applied Econometrics (2nd Ed). New York: Palgrave Macmillan. doi: 10.1057/978-1-137-41547-9

[4] Auerbach, A. J. (2013). Budget Rules and Fiscal Policy: Ten Lessons from Theory and Evidence. German Economic Review, 15(1), 84-99. doi: 10.1111/geer.12023

[5] Badinger, H., and Reuter, W. H. (2015). The Case for Fiscal Rules. Department of Economics Working Papers, Wirtschafts Universität Wien, 24. https://ideas.repec.org/p/wiw/wiwwuw/ wuwp204.html

[6] Banker, R. D. and Natarajan, R. (2008). Evaluating Contextual Variables Affecting Productivity Using Data Envelopment Analysis. Operations Research, 56(1), 48-58. doi: 10.1287/opre.1070.0460

[7] Banker, R. D., Charnes, A. and Cooper, W. W. (1984). Some Models for Estimating Technical and Scale Inefficiencies in Data Envelopment Analysis. Management Science, 30(9), 1078-1092. doi: $10.1287 /$ mnsc.30.9.1078

[8] Cooper, W. W., Seiford L. M. and Tone, K. (2006). Introduction to Data Envelopment Analysis and Its Uses. New York: Springer. doi: 10.1007/0-387-29122-9

[9] Cooper, W. W., Seiford, L. M. and Zhu, J. (2011). Handbook on Data Envelopment Analysis. International Series in Operations Research and Management Science, Springer. doi: 10.1007/14020-7798-x_1

[10] Doray-Demers, P. and Foucault, M. (2017). The politics of fiscal rules within the European Union: a dynamic analysis of fiscal rules stringency, Journal of European Public Policy, 24(6), 852-870. doi: 10.1080/13501763.2017.1296883

[11] European Commission. Stability and Growth Pact. https://ec.europa.eu/info/ business-economy-euro/economic-and-fiscal-policy-coordination_en [Accessed 9/3/2018].

[12] European Commission. The Fiscal Compact - Taking Stock. https://ec.europa.eu/info/ publications/fiscal-compact-taking-stock_en [Accessed 09/03/2018].

[13] European Commission. Numerical Fiscal Rules in EU Member Countries. https://ec. europa.eu/info/business-economy-euro/indicators-statistics/economic-databases/ fiscal-governance-eu-member-states_en [Accessed 09/03/2018].

[14] Eurostat. (2018). Glossary: Social contributions. https://ec.europa.eu/eurostat/ statistics-explained/index.php/Glossary:Social_contributions [Accessed 09/10/2018]. 
[15] Eurostat. (2018). Statistical database. https://ec.europa.eu/eurostat/data/database [Accessed 20/07/2018].

[16] Eyraud, L., Lledó, V. D., Dudine, P. and Peralta, A. (2018). How to Select Fiscal Rules: A Primer. IMF Series of Fiscal Affairs Department How-To Notes, 9, 1-24. https://www.imf.org/en/Publications/Fiscal-Affairs-Department-How-To-Notes/ Issues/2018/03/15/How-to-Select-Fiscal-Rules-A-Primer-45552

[17] Hölscher, J., Postula, M., Alińska, A. and Klepacki, J. (2018). The impact of fiscal rules on sustainable development of the Visegrad Group countries. BAFES Working Papers, Bournemouth University, 17. https://ideas.repec.org/p/bam/wpaper/bafes17.html

[18] Johnson, A. L. and Kuosmanen, T. (2012). One-stage and two-stage DEA estimation of the effects of contextual variables. European Journal of Operational Research, 220(2), 559-570. doi: $10.1016 /$ j.ejor.2012.01.023

[19] Kopits, G. and Symansky, S. (1998). Fiscal Policy Rules. IMF Occasional Paper Series, 162, 1-45. doi: 10.5089/9781557757043.017

[20] Kordić, G., Mihelja Žaja, M. and Gardijan, M. (2018) Evaluating fiscal rules efficiency in European union countries using data envelopment analysis. Proceedings of the 7th International Scientific Symposium "Economy of Eastern Croatia - Vision and Growth". Osijek: University of J. J. Strossmayer in Osijek, Faculty of Economics, 1014-1022. http://www.efos.unios.hr/ gospodarstvo-istocne-hrvatske/en/proceedings

[21] Landon, S. and Smith, C. (2017). Does the design of a fiscal rule matter for welfare? Economicl Modelling, 63, 226-237. doi: 10.1016/j.econmod.2017.01.020

[22] Lledó, V., Yoon, S., Fang, X., Mbaye, S. and Kim, Y. (2017). Fiscal Rules at a Glance. IMF Working Paper. https://www.imf.org/external/datamapper/fiscalrules/Fiscal $\% 20$ Rules $\% 20$ at $\%$ 20a\%20Glance\%20-\%20Background\%20Paper.pdf [Accessed 09/03/2018].

[23] Mihelja Žaja, M., Banker, R. D., Fang, S., Hunjet, D., Neralić, L. and Wendell, R. E. (2017). Efficiency Gains in Croatia's Electricity Distribution Centers Following Industry Structure Changes. Data Envelopment Analysis Journal, 3(1-2), 119-150. doi: 10.1561/103.00000018

[24] Pastor, J. T. and Ruiz, J. L. (2007). Variables With Negative Values in DEA, 63-84. In Cook, W. and Zhu, J. (Eds): Modelling Data Irregularities and Structural Complexities in Data Envelopment Analysis. Springer. doi: 10.1007/978-0-387-71607-7_4

[25] Schaechter, A., Kinda, T., Budina, N. and Weber, A. (2012). Fiscal Rules in Response to the Crisis - Toward the "Next-Generation" Rules. A New Dataset. IMF Working Papers, 12(187), 1-49. doi: 10.5089/9781475505351.001

[26] Trading Economics. (2018). Credit Rating. https://tradingeconomics.com/country-list/ rating [Accessed 20/07/2018]. 